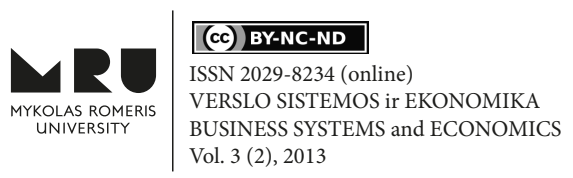

\title{
INSIGHTS ON RISK ASSESSMENT IN PERFORMANCE AUDIT
}

\author{
Dalia DAUJOTAITÉ \\ Mykolas Romeris University \\ Ateities str. 20, LT-08303 Vilnius, Lithuania \\ E-mail: daujotaite@mruni.eu \\ doi:10.13165/VSE-13-3-2-08
}

\begin{abstract}
This paper analyses the most significant developments in the audit methodology since 1990 that are related to the transition from the audit methodology based on the risk of financial statements to the methodology based on the performance process risk. Such developments in the audit methodology are presented as a result of a new approach towards risk assessment or an outcome of the new paradigm. On the other hand, the risk factors related to the performance assessment are examined and analysed as an inherent part of a performance audit. The article also deals with the general risk factors of economy, efficiency and effectiveness, introduces the performance audit efficiency model that identifies significant areas to be audited and possible research aspects.
\end{abstract}

Keywords: risk assessment, risk factors, performance audit, economy, efficiency, effectiveness.

JEL classification: M400; M420; M480.

\section{Introduction}

In Lithuania and likewise throughout the world, risk assessment issues have become an object of exceptional attention in terms of expanding the scope of the risks being assessed and developing the cognition methodologies. This has been caused by a number of factors. The ever increasing complexity of activities and the environment cause a growing uncertainty that every organisation in one way or another faces in its activities. Such uncertainties arise from limited or inaccurate information, (yet) unknown factors and other sources of uncertainties both inside the organisation and due to external factors. Such uncertainties are a source for both dangers and possibilities.

In this study, the author argues that modernizing the framework of the public administration system and seeking to ensure the effectiveness and efficiency of the system, risk assessment and identification of priorities have become an indispensable precondition. The paradigm of the most recent trends in public administration placing a focus upon resultbased management also presupposes a risk-based management: only after having assessed all material risks it is possible to efficiently manage them and achieve the best results. On the other hand, the limited resources of the institutions in charge of performance supervision 
and evaluation are most efficiently used when they are focused on the areas deemed most important and at the same time risky.

The analysis of regulatory documents showed that risk assessment and management is increasingly frequently highlighted in different European Union documents, e.g., Directive 2009/138/EC of the European Parliament indicates that all EU Member States reorganize the insurance supervision carried out thereby from the rules based supervision to the supervision focusing upon the risk of an insurer (reinsurer) and its management (risk based supervision), etc. Risk assessment is also required according to the provisions of Lithuanian regulations, such as "Risk evaluation based guidelines on the supervision of activities of economic entities" approved in 2012 and designed for business oversight institutions in relation to the implementation of risk assessment systems, and demonstrating that risk assessment is also considered increasingly important in the public sector.

Thus, the risk-assessment based approach is becoming increasingly important both in carrying out the supervision of institutional performance and also their valuation and audit. Audit and auditors play an important role in the life of the society. The statutory audit is in essence perceived as performing the functions of a supervisory authority. As stated in the Green paper Audit policy of the European Commission (2010), "Audit, alongside supervision and corporate governance, should be a key contributor to financial stability as it provides assurance on the veracity of the financial health of all companies. This assurance should reduce the risks of misstatement, and in doing so, reduce the costs of failure that would otherwise be suffered by the company's stakeholders as well as by the broader society".

Researches on interrelation between risk assessment and management have attracted considerable attention of Lithuanian and foreign researchers and practitioners. The audit risk assessment problem has been addressed by a number of foreign (Eilifsen et al., 2001; Curtis and Turley, 2007; Robson et al., 2007; Waring and Morgan, 2007; Bourn, 2007; Knechel et al., 2007; Morgan, 2009) and Lithuanian authors. The value-at-risk methodology has been the subject matter of the research carried out by Kabašinskas and Toliatiene $(1994,1997)$; Mackevičius (2001, 2005); Puškorius (2004, 2012); Lakis (2007). Risk management issues have been addressed by Tamošiūnienè and Savčuk (2007), Linartas and Staliūnienè (2012), Klimaitienè and Kanapickienè (2009), and others. As it is evident from the analysis of the references, the issues of risk are characterised by a vast diversity of the subjects researched; the issue is significant in a number of aspects, therefore, the results of any research in the area have a wide applicability spectrum; however, risk assessment in relation to performance audit still has been investigated to only a very limited extent. Until now, no integrated research on the subject of the Lithuanian performance audit risk assessment has been carried out.

The range of problems as identified above presupposes the objective of the present article, which is to examine the dynamics of the evaluation of audit risk and identify the general performance audit risk evaluation factors. Specific tasks were prescribed for the purpose of attainment of the objective defined: to discuss the general characteristics of risks and performance audit risks; to establish the relevant performance evaluation models reflecting the essence of performance audit and risk evaluation directions; to investigate the general performance audit risk factors.

Methods applied included logical analysis of research works of foreign and Lithuanian researchers, comparison, specification and generalisation of information, conceptual modelling and generalisation. 


\section{Risk assessment: changes in the audit methodology}

The analysis of economic and legal sources showed that the concept of risk has been presented in a number of different ways. COSO, 2012; Stankevičius, 2005; Robson, Humphrey, Khalifa and Jones, 2007, etc. enabled the author of the present paper to specify the concept of risk and identify its principal elements.

Risk is a future event or situation with a realistic likelihood of occurring and an unfavourable consequence or impact on the successful accomplishment of well-defined goals if it occurs (COSO, 2012). According to Charette (1989), the following characteristic features of risk, as a concept, may be distinguished: 1) risk refers to the future (we are not concerned about what was happening in the past, or is happening now since we cannot change it. However, by changing our current behaviour we may expect better results in the future); 2) anticipated changes; 3 ) risk is inevitably related to a possibility of a choice, and at the same time with an uncertainty that is a reason for that possibility.

Certain risk is inherent to any activity, and likewise to audit. For some period of time, audit companies were treating risk assessment as a separate area of activities. Some material developments in the audit methodology started becoming apparent in the eighties of the past century: the examination of financial statements prevailing at the time developed into a risk-based method. Such developments in majority of cases were related to the transition from an audit methodology based on financial statements risk to the methodology based on the performance process risk. The analysis of scientific literature (Eilifsen et al., (2001); Robson et al., (2007)) showed that the previously existing methodology did not require the auditor to acquire any high-level understanding about the strategy of the activities (business) of the auditee; though it is specifically the strategy that causes the appearance of the activity (business) risks. The knowledge about the business of the client was used to alleviate the risk potentially arising from incorrect decisions made by the auditor. A number of audit techniques have been developed for the purpose and used to obtain a required level of assurance to substantiate the auditor's opinion. The new methodology was based on the approach that anything that increases the performance (business) risk at the same increases the audit risk. This approach may be considered to represent a new paradigm that caused the appearance of new audit methodologies in research literature sources referred to in a number of ways, e.g., business risk auditing.

Conventionally, most audit companies have been viewing risk assessment as a specialised area of activities. The new approach is specific in the sense that the process of risk management involves managers and employees of all levels. Table 1 summarises the principal aspects of the transformation of the approach towards risk based on the results of the research carried out by Robson et al., 2007, on the analysis of the risk management methods (COSO, 2012; Risk Management Standard ISO 31000; Risk Management guidelines, 2004). 
Table 1. Comparison of the traditional and the new performance risk assessment paradigms

\begin{tabular}{|l|l|}
\hline \multicolumn{1}{|c|}{ The traditional paradigm } & \multicolumn{1}{|c|}{ The new paradigm } \\
\hline $\begin{array}{l}\text { Risk assessment is carried out periodically - ad } \\
\text { hoc (for cause). }\end{array}$ & $\begin{array}{l}\text { Risk assessment is a continuous and permanent } \\
\text { process. }\end{array}$ \\
\hline $\begin{array}{l}\text { Risk identification and management of controls is } \\
\text { the responsibility of the accounting, treasury and } \\
\text { the internal audit divisions. }\end{array}$ & $\begin{array}{l}\text { Risk identification and management is a responsi- } \\
\text { bility of all employees of the organisation. }\end{array}$ \\
\hline $\begin{array}{l}\text { Fragmentation - each function operates autono- } \\
\text { mously. }\end{array}$ & $\begin{array}{l}\text { Concentration - business/performance risk eva- } \\
\text { luation and management are concentrated and co- } \\
\text { ordinated by higher level supervision bodies. }\end{array}$ \\
\hline $\begin{array}{l}\text { Control is focused in order to avoid any financial } \\
\text { risk. }\end{array}$ & $\begin{array}{l}\text { Control is focused upon avoiding the unacceptable } \\
\text { business/performance risks in order to reduce it to } \\
\text { an acceptably low level. }\end{array}$ \\
\hline $\begin{array}{l}\text { Business/performance risk management policy is } \\
\text { not sufficiently supported on the part of the senior } \\
\text { management of the company or sufficiently com- } \\
\text { municated inside the audit company internally. }\end{array}$ & $\begin{array}{l}\text { A formal business/performance risk management } \\
\text { policy has been approved by the management of } \\
\text { the organisation and is communicated inside the } \\
\text { audit firm. }\end{array}$ \\
\hline $\begin{array}{l}\text { Response to the risk source only after the business/ } \\
\text { performance risk is identified. }\end{array}$ & $\begin{array}{l}\text { Business/performance risk is anticipated and pre- } \\
\text { vented by regularly overseeing the relevant busi- } \\
\text { ness/performance risk controls. }\end{array}$ \\
\hline $\begin{array}{l}\text { Incompetent staff is a primary source of business/ } \\
\text { performance risk. }\end{array}$ & $\begin{array}{l}\text { Inefficient processes are a primary business risk } \\
\text { source. }\end{array}$ \\
\hline
\end{tabular}

Source: adapted from K. Robson et al. (2007)

The new approach towards risk assessment and management constitutes an integrated, strategic assessment and management of the organisation-wide risk. The concept of risk includes any event or a phenomenon that may adversely affect the ability of a company to attain the objectives of its activities and to successfully implement its strategy. Risk assessment embraces all risks, including internal and external that may prevent the organisation from achieving its objectives. An integrated organisation-wide risk management embraces the strategy, processes, technologies and knowledge with a view to evaluating and managing uncertainties that the organisation faces in its activities.

In summary, it may be concluded that by focusing the attention upon the assessment and management of performance risk, the new paradigm enables the auditor not only to expediently understand the audit risk, but also to identify other potential risks or the areas in the organisation's operation cycle that should be improved and also to better understand the client's business risks and their impact upon the financial statements.

\section{The concept of performance audit risk}

Performance audit risk is a multidimensional concept; there is a variety of approaches, also significant differences in the definition of parameters and ratios describing it; there is no single universally recognised performance audit risk model suitable for all organisations, as the nature of operations of organisations is very different, as well as their objectives, structure and their circumstances. However, there are also some commonalities, which should be discussed more comprehensively.

Comparisons between the practice of assessing performance audit risk in different countries (Lithuanian State Control, Austrian Court of Audit, National Audit Office of the UK) 
showed that performance auditing generally follows one of three approaches in examining the performance of the audited entity. The audit may take a result-oriented approach, which assesses whether pre-defined objectives have been achieved as intended; a problem oriented approach, which verifies and analyses the causes of a particular problem(s); or a system-oriented approach, which examines the proper functioning of management systems. Also, the audit may take a combination of the three approaches. But whichever approach is adopted, performance audit risk assessment aims are examining the economy, efficiency and effectiveness criteria of the audited entity in the performance of its functions, programmes, activities, etc.

Performance audit risk is understood as an uncertainty related to the probability for the manifestation of unforeseen situations and the consequences associated thereto (Guidelines on Performance Audit Risk Analyses, 2007). Risk is a probability that under some circumstances an adverse event may actually occur and may occur at any stage of a performance audit (planning, examination phase or the follow-up monitoring, see Figure 1).

Figure 1. Stages of a performance audit and the documents drawn up

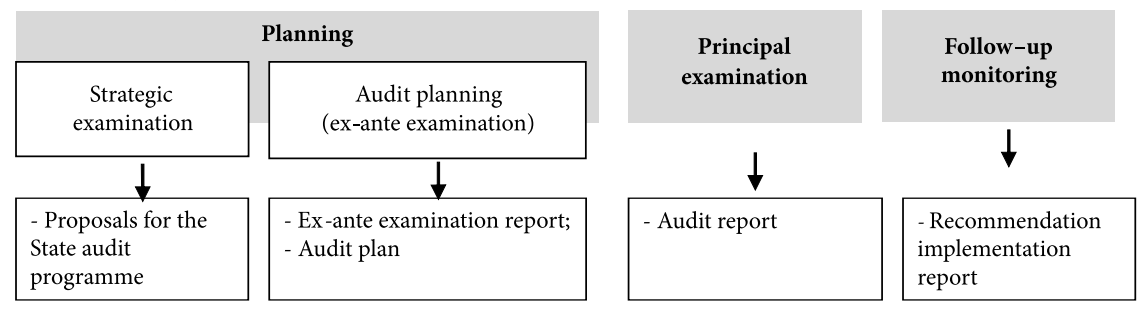

Source: Valstybès kontrolè (2010). Veiklos audito vadovas

Risk assessment is one of actions and procedures of a performance audit process to be undertaken in a priority order. Risk assessment is undertaken in the planning stage that includes: 1) collection of information; 2) risk assessment; 3) assessment of the significant risk impacts upon the programme; 4) defining and (or) improvement of audit objectives; and 5) improvement of the audit scope, methodology, audit examination programme, audit budget and/or resources (Performance Audit Manual of the ECA, 2007; Waring and Morgan, 2007). Essentially, performance audit involves an identification of weaknesses of an entity's business that are inherent to its processes, inadequate management and weak internal controls. Also, other functions include a disclosure of possibilities for further improvement and submission of recommendations. In the business sector, services of the type are undoubtedly beneficial for each company seeking optimisation of its business processes, strengthening its controls, minimising costs and increasing its profit margins.

The risk identification stage includes an evaluation of the financial significance of an item, as well as of risk factors inherent to financially relevant areas. In assessing the financial significance and the risk, an expedient approach is to assess the impact of the factors in a longer term. A financial significance of an item means its impact upon the organization: revenues, expenditures, assets and liabilities. It is an item that may produce a direct or indirect impact upon the organization. Overall, risk depends on: 1) probability of factors that may produce a negative impact upon the performance outcome; 2) impact upon the performance results. Thus, it is of utmost importance that the assessment of risk and its significance are perceived as the basis for the assessment of the each sector. 
In performing an audit and following the COSO ERM methodology (2012), a task of priority importance is to identify the risk factors related to the business of the entity. This enables the auditor to formulate his opinion of the audited entity, the areas to be audited and come up with a preliminary audit risk assessment. Risk factors include the nature and the complexity of the policy, programme and operations; diversity of the entity's objectives and tasks, consistency, clarity; appropriate operating means and their use; availability of resources; complexity of organisational structure and clear accountability structure; control systems and their quality; complexity and quality of management information, etc. (Waring and Morgan, 2007).

Risk assessment is important to all functions of the performance, where it involves the use of public funds for the attainment of certain objectives. Lost opportunities to attain certain objectives may also be considered to constitute a risk factor, e.g., opportunities to improve the performance or policy efficiency.

\section{Risk factors in performance audit}

Performance audit always starts with an analysis of the activity risk factors according to each audit assessment criterion (economy, efficiency and/or effectiveness). While gathering and analysing the information, different questions are raised and the answers to such questions make it possible to identify the general risk factors in relation to the audit subject and the object (see Tables 2, 3 and 4). The checklist questionnaires as instruments of audit activity may be general and/or specific depending on the nature of risk or the activities carried out.

An analysis of the resource risk factors from the point of view of economy requires the focus to be placed upon financial and physical resources. An indication of the economy risk is a conclusion that the costs of the resources (financial, human, material and others) used to achieve the volumes of products (services) and the level of their quality and of the overall results could have been much less than actually incurred; see Table 2.

Table 2. Risk factors related to economy

\begin{tabular}{|c|c|c|}
\hline \begin{tabular}{|c|}
$\begin{array}{c}\text { Objectives of } \\
\text { economy }\end{array}$ \\
\end{tabular} & General risk factors & $\begin{array}{c}\text { Issues to be addressed } \\
\text { in audit }\end{array}$ \\
\hline $\begin{array}{l}\text { - Minimising } \\
\text { the cost of } \\
\text { resources } \\
\text { used for an } \\
\text { activity } \\
\text { - Achieving } \\
\text { more output } \\
\text { (in terms of } \\
\text { quantity) for } \\
\text { the input }\end{array}$ & $\begin{array}{l}\text { 1) waste - usage of resour- } \\
\text { ces that are not neces- } \\
\text { sary for the attainment } \\
\text { of the expected outco- } \\
\text { mes or results; } \\
\text { 2) overpayments - resour- } \\
\text { ces are acquired disre- } \\
\text { garding the principle of } \\
\text { economy; } \\
\text { 3) luxury expenses - the } \\
\text { acquired resources are } \\
\text { of much better quality } \\
\text { than required for the } \\
\text { attainment of expected } \\
\text { outcomes or results. }\end{array}$ & $\begin{array}{l}\text { 1) does the institution acquire the required volume of resour- } \\
\text { ces of the required quality at a lowest price (e.g., the exa- } \\
\text { mination shall include the procedure for publishing public } \\
\text { procurement calls, selection of proposals, and the assess- } \\
\text { ment of the entity's possibilities to acquire the resources); } \\
\text { 2) are the financial and physical resources used efficiently; } \\
\text { 3) does the management activity meet the sound adminis- } \\
\text { tration principles and advanced management practice; } \\
\text { 4) does the institution manage its resources seeking to mi- } \\
\text { nimise the general costs; } \\
\text { 5) was it possible to prepare and implement the intervention } \\
\text { in a different way by reducing its costs; } \\
\text { 6) are the resources procured used rather than stored; } \\
\text { 7) is the staff used in all cases to a full extent; } \\
\text { 8) does the organisation apply optimisation methods. }\end{array}$ \\
\hline
\end{tabular}


In assessing the risk factors related to efficiency, the examination should start from the analysis of the types of products developed by the entities. The principal parameters of a product are its quality and quantity. The quantity is related to a quantitative denomination of a product (number of published books, number of audits performed, etc.). The quality is related to the qualitative characteristics of a product, e.g., its durability or appearance, the content of a completed training programme, compliance of the product or the approved quality requirements, etc.; see Table 3 .

Table 3. Risk factors related to efficiency

\begin{tabular}{|c|c|c|}
\hline $\begin{array}{c}\text { Objectives of } \\
\text { efficiency }\end{array}$ & General risk factors & $\begin{array}{c}\text { Issues to be addressed } \\
\text { in audit } \\
\end{array}$ \\
\hline $\begin{array}{l}\text { The relationship } \\
\text { between outputs } \\
\text { and the resour- } \\
\text { ces used to pro- } \\
\text { duce them } \\
\text { - Are resour- } \\
\text { ces spent on } \\
\text { outputs that } \\
\text { produce most } \\
\text { outcome? }\end{array}$ & $\begin{array}{l}\text { 1) loss - having used the } \\
\text { resources, the desired } \\
\text { outcomes have not } \\
\text { been achieved; } \\
\text { 2) less than optimal } \\
\text { resource to outcome } \\
\text { ratio - low labour } \\
\text { efficiency level; } \\
\text { 3) slow implementation } \\
\text { of the intervention; } \\
\text { 4) unidentified and } \\
\text { uncontrolled eternal } \\
\text { factors - expenses } \\
\text { imposed upon natural } \\
\text { and legal persons that } \\
\text { are not covered by the } \\
\text { intervention of the } \\
\text { subject. }\end{array}$ & $\begin{array}{l}\text { 1) are the programmes properly prepared and planned; } \\
\text { are they clear and consistent; } \\
\text { 2) are the objectives and the provided measures (legal, } \\
\text { financial, etc.) appropriate, consistent and relevant; } \\
\text { 3) are the works performed within suitable terms avoid- } \\
\text { ing any delayed or unnecessary expenses; } \\
\text { 4) was the activity planned, organised and implemented } \\
\text { in an appropriate manner; } \\
\text { 5) assess the efficiency of the structure of the organisa- } \\
\text { tion, decision making process and the programme } \\
\text { implementation management system; } \\
\text { 6) does the programme implement or duplicate other } \\
\text { related programmes, partly overlap with them, or } \\
\text { contradict the same; } \\
\text { 7) does the quality of public services meet the expecta- } \\
\text { tions of people and the set up objectives; } \\
\text { 8) determine the suitability of the system for the assess- } \\
\text { ment and monitoring of the programme efficiency, } \\
\text { and the reporting about the programme; } \\
\text { 9) assess the efficiency of the public investment and the } \\
\text { programme(s) and their components, i.e., have the } \\
\text { objectives been attained; } \\
\text { 10) identify the actions preventing the attainment of the } \\
\text { satisfactory efficiency or objectives; } \\
\text { 11) analyse the reasons for the outcome received and } \\
\text { the problems identified with a view to identifying } \\
\text { the methods to enhance the efficiency of the perfor- } \\
\text { mance and programmes of the State; } \\
\text { 12) determine a relative benefit of alternative methods } \\
\text { in ensuring better results or eliminating the factors } \\
\text { reducing the efficiency of the programme. }\end{array}$ \\
\hline
\end{tabular}

Source: prepared according to Performance Audit Manual, 2007; Guidelines on Performing Performance Audit, 2004; Waring and Morgan, 2007; Daujotaitè and Mačerinskiené, 2008

In examining the risk factors related to the outcome quantity, the principal question to be answered is whether the services (goods) meet the requirements and the needs. One of the methods used in determining the adequacy of the programme outcome is the examination of the tasks or operating processes that were not performed. Another method suggests 
measurement of the outcome ratio to the demand (service applications). The outcome quality is demonstrated by the absence of defects in completed units, as well as the adequacy of services. Quality could be viewed as an attribute of the outcome unit; see Table 4.

Table 4. Risk factors related to effectiveness

\begin{tabular}{|c|c|c|}
\hline $\begin{array}{l}\text { Objectives of } \\
\text { effectiveness }\end{array}$ & General risk factors & $\begin{array}{c}\text { Issues to be addressed } \\
\text { in audit }\end{array}$ \\
\hline $\begin{array}{l}\text { The extent to which } \\
\text { objectives have been } \\
\text { achieved and the } \\
\text { relationship between } \\
\text { the intended impacts } \\
\text { and actual impacts of } \\
\text { an activity. } \\
\text { - Are intended } \\
\text { impacts actually } \\
\text { achieved? }\end{array}$ & $\begin{array}{l}\text { 1) wrongly drawn up } \\
\text { policy - inadequate } \\
\text { evaluation of needs, } \\
\text { unclear and inconsistent } \\
\text { objectives, inadequate } \\
\text { intervention measures, } \\
\text { or the impracticability of } \\
\text { objectives; } \\
\text { 2) management failures - } \\
\text { objectives not attained, } \\
\text { as the attainment of } \\
\text { objectives was not per- } \\
\text { ceived as a priority by the } \\
\text { management. }\end{array}$ & $\begin{array}{l}\text { 1) are the objectives of a programme properly } \\
\text { defined, presented according to specific levels, } \\
\text { and to what extent they were attained. Are the } \\
\text { programme objectives attainable with justifi- } \\
\text { able costs; } \\
\text { 2) are the human, financial and other resources } \\
\text { used efficiently; } \\
\text { 3) are the programmes, entities and activities } \\
\text { efficiently managed, regulated, organised and } \\
\text { implemented, monitored and assessed; } \\
\text { 4) does the performance of the organisation } \\
\text { correspond to the prescribed objectives and } \\
\text { requirements; } \\
\text { 5) are the public services of appropriate quality, } \\
\text { customised to the customer needs and pro- } \\
\text { vided in a timely manner. } \\
\text { 6) establish whether the monitored direct or } \\
\text { indirect social, economic, environmental } \\
\text { impact appeared because of the activities or } \\
\text { for other reasons. }\end{array}$ \\
\hline
\end{tabular}

Source: prepared according to Performance Audit Manual, 2007; Guidelines on Performing Performance Audit, 2004; Waring and Morgan, 2007; Daujotaite and Mačerinskienė, 2008

Performance audit practice uses different risk assessment methodologies, and as of now, there is no unanimous decision as to their appropriateness for addressing a number of outstanding issues. Risk assessment is one of the important stages of the performance audit process; therefore, a number of auditing standards contains references to risks, risk factor evaluation and management. Different literature sources demonstrate numerous attempts to design mathematical audit risk assessment models; auditors, however, should not use such models unconditionally, to try to express risk components in quantifiable terms. Quantitative evaluation of audit risk is not considered a practicable approach, and this is due to the numerous variables and a constantly changing environment that in its own turn affect the variables. An auditor should consider the audit risk in its each form of manifestation related to each significant area being assessed.

\section{Application of the performance audit risk model: a theoretical study}

An essential attribute of the modern performance assessment is the abundance of performance assessment frameworks. According to Rupšys and Boguslauskas (2003), proposed performance assessment frameworks differ in their complexity, ranging from rather simple 
and unsophisticated (such as the system of results and determining factors) to rather complex and sophisticated performance assessment framework (such as balanced scorecards or a performance prism). Therefore, the possibilities of adapting such models, as well as their practical adaptability differ considerably.

A common tool for managers and performance auditors is a logical model. This is one of the most widely used logical performance models reflecting both the logics of performance audit and facilitating the understanding of the reason-effect path (see below).

\section{INPUTS $\rightarrow$ PROCESSES $\rightarrow$ OUTCOMES}

The model presented is described as a systemic and visual method to present the knowledge on the interrelation between the resources available for an organisation/programme, planned activities and the expected outcomes (Pollitt and Bouckaert, 2003; Performance Audit Manual of the European Court of Auditors, 2007, Performance Audit Manual of the National Audit Office of Lithuania, 2010).

The analysis of literature showed that problem areas identified in risk analysis can be approached using performance audit's perspectives model, which retains the essence of the primary logic model (see Figure 2).

Figure 2. Performance audit perspectives derived from the effectiveness model

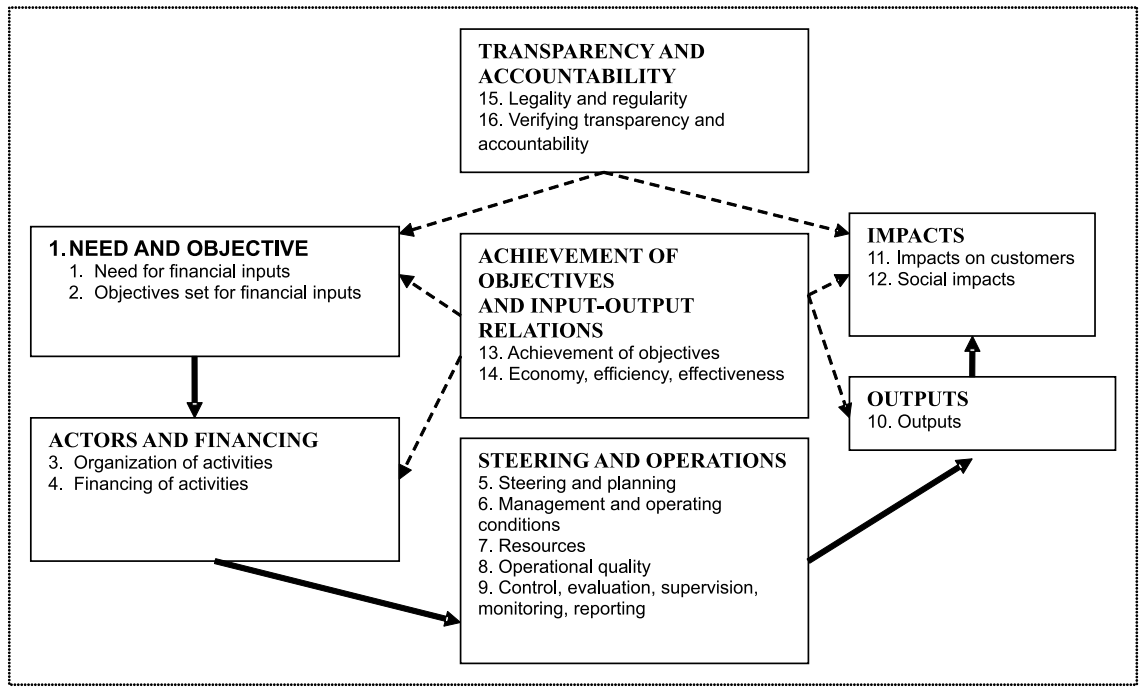

Source: Guidelines on Performance Audit Risk Analysis, 2007

As it is evident from Figure 2, performance audit risk depends on a number of factors. Sufficient attention has not yet been devoted to a classification or survey of such factors in research literature. The factors affecting performance audit risk should be classified according to two main factors: 1) external risk factors; 2) internal risk factors (see Table 5). Below are some questions that can be used to outline potential risks; see Table 5. 
Table 5. Types of risks in performance audit

\begin{tabular}{|c|c|}
\hline Risk factors & Issues considered \\
\hline External risk factors & $\begin{array}{l}\text { It may cover the following: climate change, natural calamities, international } \\
\text { crises, wide scope pandemics, globalisation developments, government } \\
\text { activities, corruption, inadequate judicial systems, etc. }\end{array}$ \\
\hline $\begin{array}{l}\text { Risk factors related to } \\
\text { the implementation of } \\
\text { needs and objectives }\end{array}$ & $\begin{array}{l}\text { Is there any risk that the social needs related to the activities and the re- } \\
\text { sources have changed but the administration did not react to such changes? } \\
\text { Have the resources intended to be used been defined having regard to the } \\
\text { public interests, as established by the Parliament or its resolutions? }\end{array}$ \\
\hline $\begin{array}{l}\text { Risk factors related to } \\
\text { the organisation and } \\
\text { financing of the activities } \\
\text { carried out }\end{array}$ & $\begin{array}{l}\text { Are there any problems related to the allocation of funding? Does the finan- } \\
\text { cing system itself facilitate economy and efficiency? Is the funding to the } \\
\text { activities allocated from more than one source? Do Government subsidies, } \\
\text { state aid measures or the funding from the EU sources constitute a large } \\
\text { part of the general financing? }\end{array}$ \\
\hline $\begin{array}{l}\text { Management and per- } \\
\text { formance risk factors }\end{array}$ & $\begin{array}{l}\text { Does the management perform properly and appropriately applies mana- } \\
\text { gement measures? Are the operations complex and complicated? Are the } \\
\text { operations fragmented? Have any organisational changes in the operations } \\
\text { of the company taken place? Have any significant legal system reforms been } \\
\text { implemented, or any development projects affecting the operations? Are } \\
\text { large amounts of taxes collected in the sector under the administration? Are } \\
\text { the operations managed in a way facilitating the attainment of the relevant } \\
\text { objectives? Are the ancillary areas of activities, such as procurement, infor- } \\
\text { mation technologies, immovable property and human resources organised } \\
\text { properly? Are any significant procurement transactions effected in the sec- } \\
\text { tor being managed? Have any problems been encountered while carrying } \\
\text { out the supervision and monitoring activities? Are the supervisory autho- } \\
\text { rities submitted accurate and truthful information? Have any gaps been } \\
\text { established in the area of reporting? }\end{array}$ \\
\hline $\begin{array}{l}\text { Risk factors related to } \\
\text { performance results and } \\
\text { attainment of results }\end{array}$ & $\begin{array}{l}\text { Are there any problems related to the performance of operations? Do the } \\
\text { objectives attained justify the resources used? Have any problems occurred } \\
\text { while attaining the established objectives? Are the activities economic, ef- } \\
\text { ficient, productive and justifying the costs? Was the administration able to } \\
\text { properly assess the economy, effectiveness and efficiency of expenses? Is the } \\
\text { administration able of making an influence on the attainment of objectives? }\end{array}$ \\
\hline Impact risk factors & $\begin{array}{l}\text { Have the activities produced any undesirable effect upon the clients? Has } \\
\text { the anticipated social effect been achieved? Have the activities produced any } \\
\text { unwanted effect? What is the financial significance of the unwanted effect? } \\
\text { Have any problems arisen in assessing the effect? }\end{array}$ \\
\hline $\begin{array}{l}\text { Transparency and repor- } \\
\text { ting risk factors }\end{array}$ & $\begin{array}{l}\text { Have any infringements been established? Was the administration properly } \\
\text { executing the budget? Have any irregularities or errors been established? } \\
\text { Were the objectives or the financing procedure defined and presented in a } \\
\text { transparent and appropriate manner? Was the information presented on } \\
\text { the activities sufficient, accurate and complete? Did the citizens describe the } \\
\text { activities in a sufficiently transparent manner? Were the activities subject to } \\
\text { any criticism? }\end{array}$ \\
\hline
\end{tabular}

Source: adapted from Guidelines on Performance Audit Risk Analyses, 2007; Performance Audit Manual, 2007 


\section{Conclusions}

The paradigm of the new public management highlighting the taking of evidencebased decisions and result-driven management presupposes the evaluation of performance based on the assessment of risk. The limited resources of the institutions in charge of the supervision and evaluation of activities are used in a most efficient manner when they are focused upon the most important and risky areas.

The analysis of the developments in the audit methodology shows some essential changes in the area related to the transition from the audit methodology based on the risk of financial statements to the methodology based on business process risk. The new type methodology is based on the approach that any developments or factors that increase business risk at the same time increase the audit risk. This approach may be viewed as a new paradigm that caused the appearance of new audit methodologies.

The comparison of the principal aspects of the approach towards risk shows that the new paradigm focused upon the assessment and management of business risks enables the auditor not only to better understand the audit risk, but also to identify other potential risks or the areas in the organisation business cycle that need to be improved, as well as to better understand the organisation's business risks and their impact upon financial statements. Performance audit may assimilate the theoretical and practical basis in performing the risk assessment employed by other audit types (especially financial audit).

Performance audit includes individual structural elements of the input-output model and reflects the essence of risk assessment in performance audit. This risk assessment model may facilitate the identification of significant areas to be audited.

The analysis of risk factors presented in Tables 2, 3 and 4 shows that risk is assessed according to each performance audit evaluation criterion (economy, efficiency and/or effectiveness). While gathering and analysing the information, different questions are raised and the answers to such questions make it possible to identify the general risk factors in relation to the subject and the object of the audit.

\section{References}

Bourn, J. (2007). Public sector auditing: it is value for money? UK: John Wiley \& Sons.

Charette, R. (1989). Software engineering risk analysis and management. New York: McGraw-Hill.

COSO. (2012). Risk assessment in practice. Retrieved November 27, 2012 from http://www.coso.org/ Curtis, E., and Turley, S. (2007). The business risk audit - A longitudinal case study of an audit engagement. Accounting, Organizations and Society, 32(4/5): 439-461.

Directive 2009/138/EC of the European Parliament and of the Council of 25 November 2009 "On the taking up and pursuit of the business of Insurance and Reinsurance (Solvency II). Retrieved December 14, 2012 from http://eur- lex.europa.eu

Daujotaitė, D., and Mačerinskiené, I. (2008). Development of performance audit in public sector.

Finance Engineering. Retrieved July 27, 2013 fromhttp://ww w.theiia.org/chapters/pubdocs/303/D. Daujotaite,_I.Macerinskiene_Developement_of_Performance_Audit_2008_.pdf

Eilifsen, A., Knechel, W. R., and Wallage, P. (2001). Application of the business risk audit model: A field study. Accounting Horizons, 15(3): 193-207.

European Commission. (2010). Green paper - audit policy: Lessons from the crises. Retrieved September 4, 2012 from http://ec.europa.eu/internal_market/consultations/docs/2010/audit/ green_paper_audit_en.pdf 
European Court of Auditors. (2007). Performance audit manual. Retrieved November 23, 2012 from http://europa.eu/about-eu/institutions-bodies/court-auditors/index_lt.htm

Government Auditing Standards, 2011 Revision (GAO-12-331G). Retrieved July 18, 2013

from http://www.gao.gov/yellowbook

Guidelines on performance audit risk analysis. (2007). Retrieved February 14, 2013 from http://www. vtv.fi/files/19/Guidelines_on_Performance_Audit_Risk_Analyses.pdf Kabašinskas, J., and Toliatienè, I. (1994). Pažintis su auditu. Vilnius: Amžius.

Kabašinskas, J., and Toliatienė, I. (1997). Auditas. Vilnius: Perkūno leidykla.

Klimaitiené, R., and Kanapickienė, R. (2009). Biudžetų naudojimas įmonės rizikos valdymo procese. Ekonomika ir vadyba: aktualijos ir perspektyvos, 2(15): 112-118.

Knechel, R. W., Salterio, S., and Ballou, B. (2007). Auditing: assurance and risk. Thomson: S o u t h Western College Publishing.

Lakis, V. (2007). Audito sistema: raida ir problemos: monografija. Vilnius: Vilniaus Uuniversiteto Leidykla.

Linartas, A., and Staliūnienė, J. D. (2012). Rizikos vertinimo modelio taikymas atskleidimų klasifikavimu. Apskaitos ir finansų mokslas ir studijos: problemos ir perspektyvos. Mokslo žurnalas, 1(8): 121-129.

Mackevičius, J. (2001). Auditas: teorija, praktika, perspektyvos: monografija. Vilnius: Lietuvos Mokslas.

Mackevičius, J. (2005). Audito rizikos veiksnių vertinimas. Organizacijų vadyba: sisteminiai tyrimai. Retrieved January 20, 2013 from http://archive.minfolit.lt/arch/1/321.pdf

Morgan, S. L. (2009). Risk based performance audit project planning. Guam: APIPA.

Pollitt, Ch., and Bouckaert, G. (2003). Viešojo valdymo reforma. Lyginamoji analizè. Vilnius: Algarvè.

Puškorius, S. (2004). Veiklos auditas: monografija. Vilnius: Lietuvos teisès universitetas.

Risk Management Standard AS/NZS ISO 31000. Retrieved February 3, 2013 from http://www.safetyrisk.com.au/new-risk-management-standard-asnzs-iso-31000/

Rizikos vertinimu pagrịstos ūkio subjektų veiklos priežiūros gairès. (2012). Retrieved January 13, 2013 from http://www.ukmin.lt/uploads/documents/imported/lt/verslo_aplinka/rizikos\%20gaires_ galutinis.pdf

Risk Management guidelines. (2004). Companion to AS/NZS 4360:2004. Retrieved February 3, 2013 from http://www.mwds.com/AS4me_files/AS-NZS\%204360-2004\%20Risk\%20Management.pdf

Robson, K., Humphrey, Ch., Khalifa, R., and Jones, J. (2007). Transforming audit technologies: Business risk audit methodologies and the audit field. Accounting, Organizations and Society, 32: 409-438.

Rupšys, R., and Boguslauskas, V. (2007). Measuring performance of internal auditing: Empirical evidence. Engineering Economics, 5(55).

Stankevičius, R. (2005). Rizikos samprata ir jos valdymas muitineje. Jurisprudencija, 69(61): 70-76.

Tamošiūnienė, R., and Savčuk, O. (2007). Rizikos valdymas Lietuvos organizacijose - sąsajos su vidaus auditu ir finansinių ataskaitų kokybe. Verslas: teorija ir praktika, 8(4): 204-213.

Valstybès kontrolè (2010). Veiklos audito vadovas. Vilnius: Valstybès kontrolè.

Waring, C. G., and Morgan, S. L. (2007). Performance accountability and combating corruption. Washington, D.C.: The World Bank. 


\section{VEIKLOS AUDITO RIZIKOS VERTINIMO İŽVALGOS}

\section{Dalia DAUJOTAITÉ}

Mykolo Romerio universitetas, Lietuva

Santrauka. Straipsnyje analizuojami esminiai audito metodologijos pokyčiai, kurie pasireiškè nuo 1990 metų ir yra susiję su perėjimu nuo audito metodologijos, pagrịstos finansinių ataskaitų rizika, prie metodologijos, grindžiamos veiklos procesų rizika. Audito metodologijos pokyčiai pristatomi kaip naujo požiūrio ị rizikos vertinimą arba naujos paradigmos rezultatas. Kita vertus, veiklos vertinimo rizikos faktoriai tiriami ir analizuojami kaip veiklos audito sudetiné dalis veiklos audito procese. Nagrinejjami ekonomiškumo, efektyvumo ir rezultatyvumo bendrieji rizikos faktoriai ir jų vertinimo aspektai, pristatomas veiklos audito veiksmingumo modelis, rodantis reikšmingas audituotinas sritis ir galimus tyrimo aspektus.

Reikšminiai žodžiai: rizikos vertinimas, rizikos faktoriai, veiklos auditas, ekonomiškumas, efektyvumas, rezultatyvumas. 